\title{
The Northern-Crimean Canal as a Model Object for Radioecological Study of the Chernobyl Radionuclides Transport to the Black Sea
}

\author{
G.G. Polikarpov, G.E. Lazorenko, N.N. Tereshchenko, \\ N.Yu. Mirzoyeva
}

\author{
Kovalevsky Institute of Marine Biological Researches, Russian Academy of Sciences, \\ Sevastopol, Russian Federation \\ e-mail: g.e.lazorenko@gmail.com
}

\begin{abstract}
Radioecological study of the irrigation system of the Northern-Crimean Canal (NCC) was carried out to assess its role in the transport of the Chernobyl-originated long-lived radionuclides to the Karkinitsky Bay in the Black Sea north-western part. For this study, five main stations were selected and disposed along the NCC mainstream at the distances 0, 28, 84, 125 and $150 \mathrm{~km}$. Two local polygons in the Krasnoperekopskiy and Razdolnenskiy regions of the Crimea were chosen as the model objects to analyze their role in transport of the ${ }^{90} \mathrm{Sr},{ }^{137} \mathrm{Cs}$ and ${ }^{238,239,240} \mathrm{Pu}$ to the Karkinitsky Bay during the irrigation period in April-October, 1992-1995. ${ }^{137} \mathrm{Cs}$ and plutonium isotopes were analyzed in bottom sediments and soil under crops because their concentrations in water were higher the Lower Limit Detection (LLD) only at the beginning of the NCC. Water, bottom sediments, five aquatic plants (pondweed clasping-leaved Potamogeton perfoliatus and fennel-leaved (Potamogeton pectinatus, Ceratophyllum Ceratophyllum demersum and Myriophyllum spicatum, cane Scirpus lacustris), four crops (alfalfa Medicago sativa, rice Oriza sativa, wheat Triticum durum and maize Zea mays) and soils under them were collected for ${ }^{90} \mathrm{Sr}$ analyses. ${ }^{137} \mathrm{Cs}$ activity in the samples was measured on the $\mathrm{Ge} / \mathrm{Li}$ detector DGDK-100. After radiochemical procedures ${ }^{90} \mathrm{Sr}$ was measured by the lowbackground liquid scintillation beta-counter «Quantulus 1220», plutonium isotopes - by the alphaspectrometer EG\&G ORTEC OCTETE PC. It was revealed that irrigated soils, bottom sediments of the NCC mainstream, its branch and drainage systems constitute the main storage of ${ }^{137} \mathrm{Cs}$ and plutonium isotopes. Therefore, the NCC irrigation system is considered to be a natural buffer preventing further transfer of these radionuclides to the Karkinitsky Bay. At the same time, ${ }^{90} \mathrm{Sr}$ is characterized by almost uniform distribution in all the components of the NCC irrigation ecosystem.
\end{abstract}

Keywords: ${ }^{90} \mathrm{Sr},{ }^{137} \mathrm{Cs}$, plutonium isotopes, Northern-Crimean Canal irrigation system.

DOI: 10.22449/1573-160X-2015-3-25-34

(C) 2015, G.G. Polikarpov, G.E. Lazorenko, N.N. Tereshchenko, N.Yu. Mirzoyeva

(C) 2015, Physical Oceanography

Introduction. During the first months after the accident at the Chernobyl nuclear power plant (ChNPP) the atmospheric transfer of the Chernobyl-originated radionuclides to the Crimea and to the north-western part of the Black Sea was decisive. A waterway as a main sourse of the Chernobyl radionuclides transport to this marine region was formed by the flood waters from the upper Dnieper and its tributaries in the Kakhovka Reservoir and their further motion through the Dnieper-Bug estuary to the north-western part of the Black Sea. Much smaller volumes of the Dnieper water from the Kakhovka Reservoir got to this marine region after irrigation of agricultural lands in the north-western part of the Crimea and some areas of the Kherson District of Ukraine and then, due to water discharge, to the Karkinitsky Bay. These lands are irrigated by the water system of artificial Northern-Crimean Canal (NCC). It was found that during five years after the ChNPP accident concentrations of long-lived radionuclides ${ }^{90} \mathrm{Sr},{ }^{137} \mathrm{Cs}$ and isotopes of plutonium in the Dnieper water entering the NCC from the Kakhovka Reservoir significantly decreased. Study of the NCC water system demonstrated stabilization of the radioecological situation in this area by 1992. This information was confirmed PHYSICAL OCEANOGRAPHY NO. 3 (2015) 
by our data on concentrations of ${ }^{90} \mathrm{Sr},{ }^{137} \mathrm{Cs}$ and plutonium isotopes in water, suspended matter and sediments. Stable situation was used to analyze spatial and temporal distribution of these radioactive elements in the components of the NCC water system in 1986 - 1992 as compared to the corresponding data for the following four years. The main purpose of this work is to assess the role of the NCC irrigation system in transport of ${ }^{90} \mathrm{Sr},{ }^{137} \mathrm{Cs}$ and plutonium isotopes from the Kakhovka Reservoir to the Karkinitsky Bay.

Material and methods. The Karkinitsky Bay is situated in the north-western part of the Black Sea (Fig. 1). The Dnieper waters inflow the NCC from the Kakhovka Reservoir in the point of its main facilities - near the town Novaya Kakhovka (Fig. 2, station 1). For this radioecological study, five main stations were selected and disposed along the NCC mainstream at the distances $0,28,84,125$ and $150 \mathrm{~km}$ (Fig. 2, stations $1-5$ ). Two local polygons in the Krasnoperekopsky and Razdolensky regions of the Crimea were chosen as the model objects to analyze their role in transport of the ${ }^{90} \mathrm{Sr},{ }^{137} \mathrm{Cs}$ and ${ }^{238,239,240} \mathrm{Pu}$ to the Karkinitsky Bay during the irrigation period in April - October, 1992 - 1995. This period was characterized by more or less stable concentrations of these radionuclides in the NCC water system [1 - 4]. Stations 4 and 5 were the starting points of the polygons (Fig. 2). The process of agricultural fields' irrigation was completed at stations 4A and 5A located at the distance 130 and $160 \mathrm{~km}$ from the NCC beginning (Fig. 2).

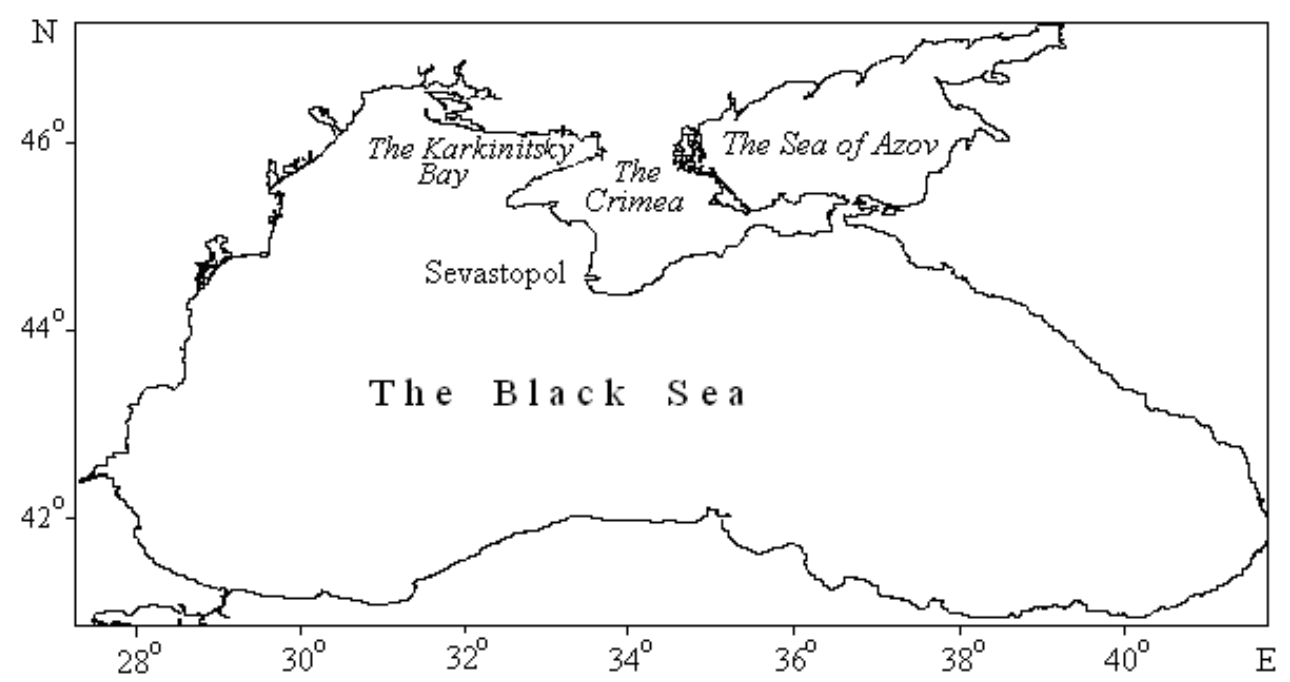

Fig. 1. The scheme-map of the Black Sea and the Karkinitsky Bay

The samples for radioactive analyses were prepared by standard procedures [5 - 8]. ${ }^{137}$ Cs concentration in the samples was measured by Ge/Li detector DGDK100. The methods of ${ }^{90} \mathrm{Sr}$ and plutonium isotopes' determination were based on radiochemical analyses of these radionuclides [5 - 8]. ${ }^{90} \mathrm{Sr}$ activity was measured by low-background liquid scintillation beta-counter «Quantulus 1220». Plutonium isotopes were measured by alpha-spectrometer EG\&G ORTEC OCTETE PC. The radionuclides' concentrations in surface water, bottom sediments and agricultural crops are given in $\mathrm{Bq} \cdot \mathrm{m}^{-3}$ and $\mathrm{Bq} \cdot \mathrm{kg}^{-1}$ dry weight $(\mathrm{dw})$, respectively. 
Samples of water, bottom sediments, five aquatic plants (Potamogeton perfoliatus and (Potamogeton pectinatus, Ceratophyllum Ceratophyllum demersum and Myriophyllum spicatum, cane Scirpus lacustris), four crops (alfalfa Medicago sativa, rice Oriza sativa, wheat Triticum durum and maize Zea mays) and corresponding soils were collected for the radioactive study.

Cesium and plutonium radionuclides were analyzed in bottom sediments and soil since their concentrations were higher than the Lower Limit Detection at station $1[1-4,9]$. In the samples collected at other sampling locations the concentrations of these radionuclides were lower than Lower Limit Detection. Samples of soils $(0-5 \mathrm{~cm})$ under main crops were collected on the irrigated agricultural fields and on the virgin areas (salt-marsh) by $20 \times 25 \mathrm{~cm}^{2}$ plots. Vertical distribution of ${ }^{137} \mathrm{Cs}$ and ${ }^{90} \mathrm{Sr}$ was investigated in the $0-20 \mathrm{~cm}$ layers of soils under the irrigated alfalfa and in natural undisturbed salt-marshes which were chosen for comparison since they were not irrigated and located far away from the NCC. In all the samples the confidence interval did not exceed $20 \%$ of the data mean value.

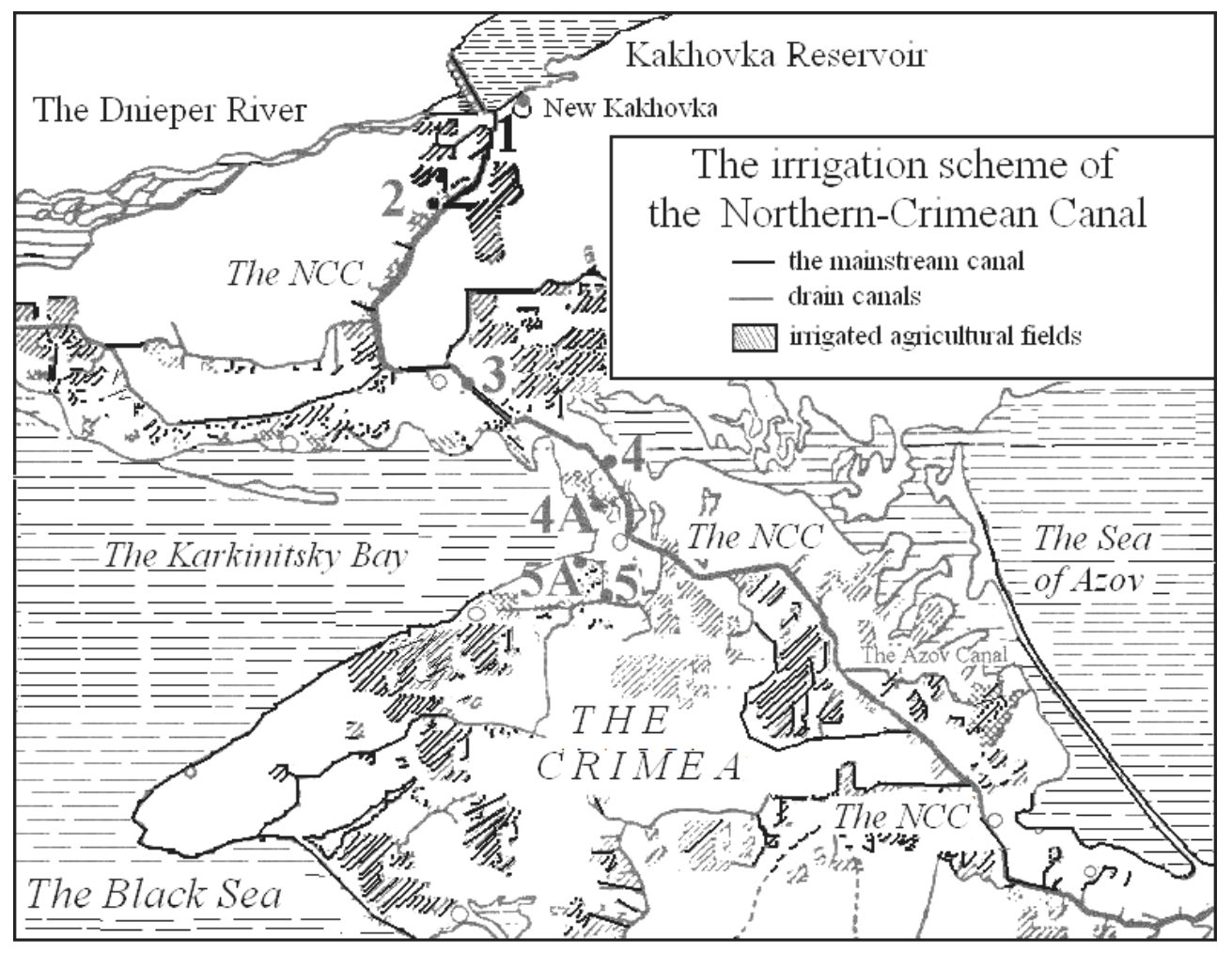

Fig. 2. Sampling location along the NCC

Results and discussion. ${ }^{137} \mathrm{Cs}$, as well as plutonium isotopes, are found in water, mainly, in suspended matter. In 1992 concentration of ${ }^{137} \mathrm{Cs}$ in the suspended matter samples collected in the Kakhovka Reservoir just before the Dnieper water inflow to the NCC was equal to $4.2 \mathrm{~Bq} \cdot \mathrm{kg}^{-1} \mathrm{dw}[1,2]$. In $1992-1995$ the range of its values was $3.8-4.0 \mathrm{~Bq} \cdot \mathrm{kg}^{-1} \mathrm{dw}[1,2] .{ }^{238} \mathrm{Pu}$ and ${ }^{239,240} \mathrm{Pu}$ concentrations in suspended matter in 1992 varied from 3.34 to 4.5 and from 6.47 to $7.65 \mathrm{mBq} \cdot \mathrm{kg}^{-1} \mathrm{dw}$, respectively [1, 2]. The plutonium isotopes' concentrations in suspended matter 
diminished by almost 25 times due to large distance from the place where the Dnieper water from Kakhovka Reservoir inflowed the NCC. For ${ }^{238} \mathrm{Pu}$ they varied from 3.92 to $0.16 \mathrm{mBq} \cdot \mathrm{kg}^{-1} \mathrm{dw}$, and for ${ }^{239,240} \mathrm{Pu}-$ from 7.06 to $0.28 \mathrm{mBq} \cdot \mathrm{kg}^{-1} \mathrm{dw}$ $[1,2]$ (Fig. 3). Concentrations of ${ }^{137} \mathrm{Cs}$ and plutonium isotopes in bottom sediments decreased with distance from the NCC beginning [1, 2, 4, 9] (Fig. 4).

The tendencies of changes of ${ }^{137} \mathrm{Cs}$ concentrations in the NCC bottom sediments in $1992-1995$ [1, 2, 4] are represented in Fig. 5. The role of the irrigated agricultural fields in extraction of ${ }^{137} \mathrm{Cs}$ from the Dnieper water is given in Fig. 6 $[3,4]$.

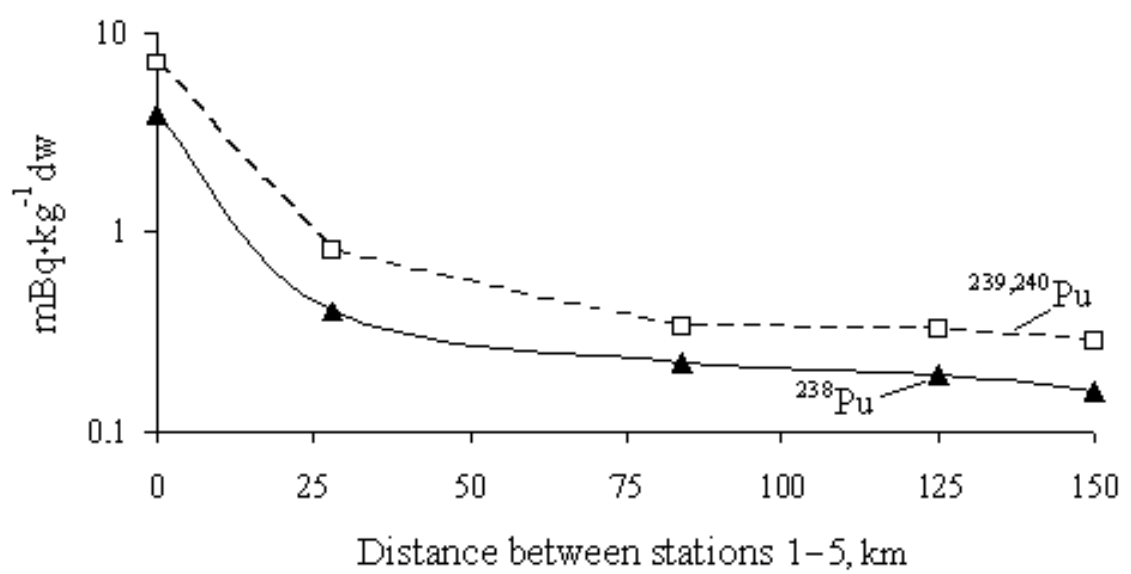

Fig. 3. The distribution of plutonium isotopes in suspended matter of the NCC, 1992

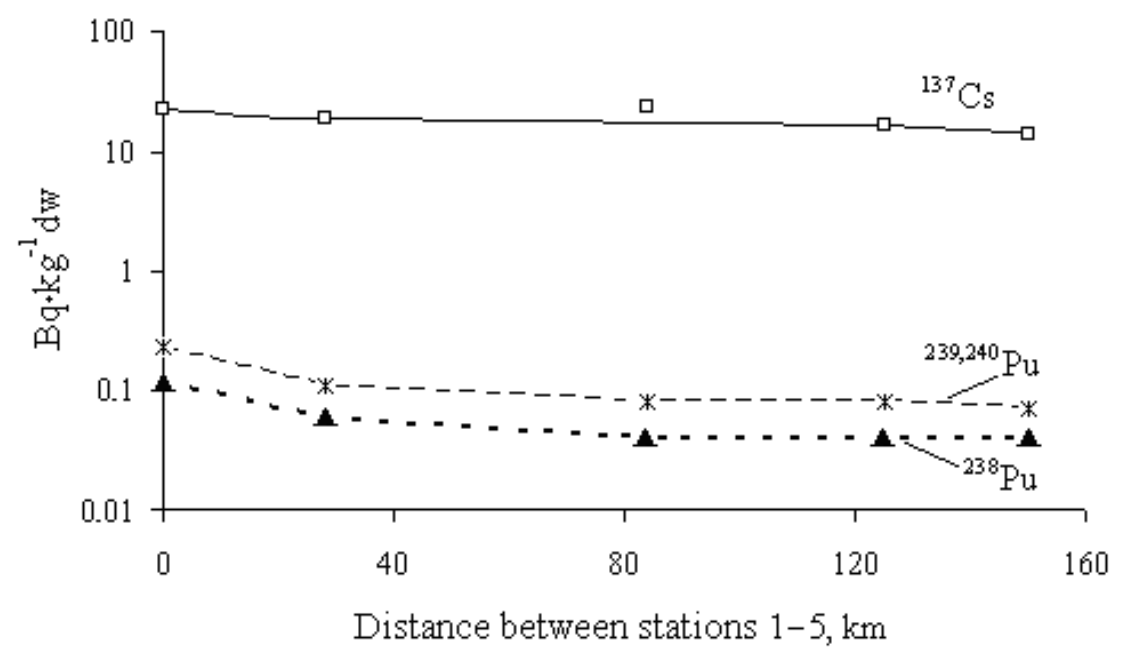

Fig. 4. ${ }^{137}$ Cs and plutonium isotopes in the NCC bottom sediments, 1992

${ }^{137} \mathrm{Cs}$ accumulation by the investigated soils along the NCC depended on their type $[1,4,10,11]$. It is seen that maximum concentration of ${ }^{137} \mathrm{Cs}$ (8.9 Bq· kg-1 dw) was found in the $5-10 \mathrm{~cm}$ layer of the soil under the irrigated alfalfa (Fig. 7). 
In the same time the radiocesium vertical profile in the salt-marsh soil was different. The highest contents of this radionuclide were found in the layers $0-2 \mathrm{~cm}$ (59\%) and $2-5 \mathrm{~cm}$ (26\%) (Fig. 7).

Thus, $85 \%$ of ${ }^{137} \mathrm{Cs}$ are in the $0-5 \mathrm{~cm}$ layer of virgin soil. It is shown that such type of soils can be considered a model object used to control and assess radioactive contamination of an area from possible atmospheric sources.

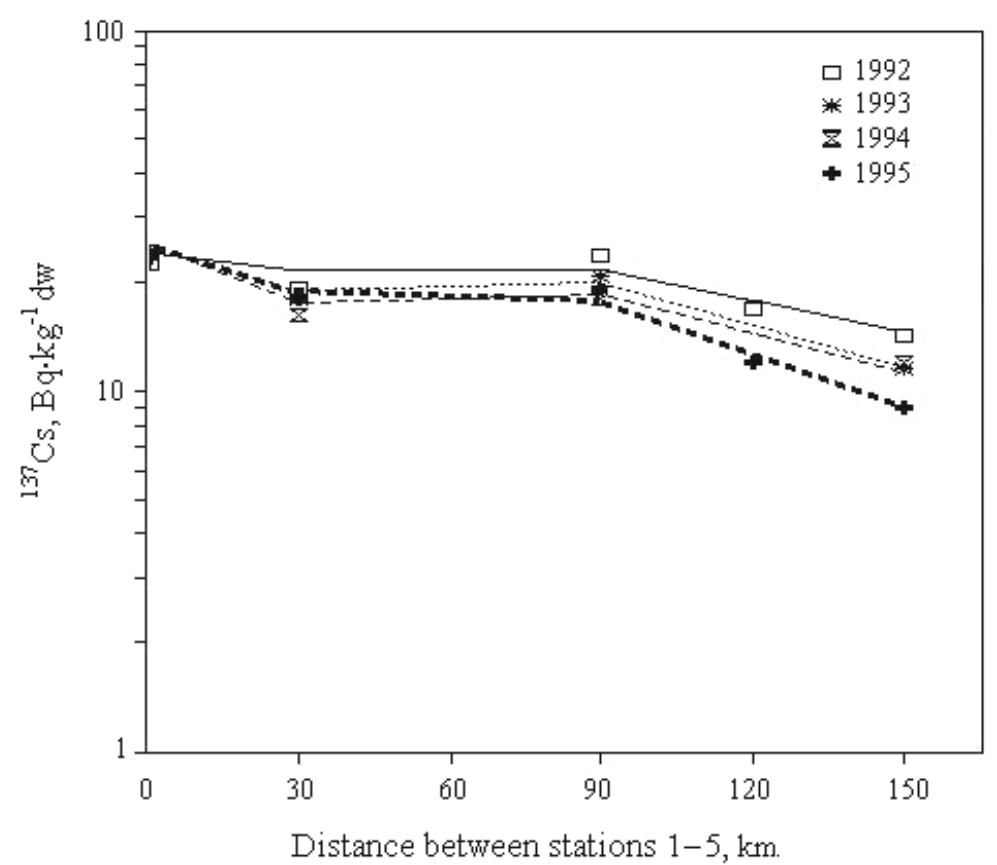

Fig. 5. ${ }^{137} \mathrm{Cs}$ in the NCC bottom sediments, $1992-1995$

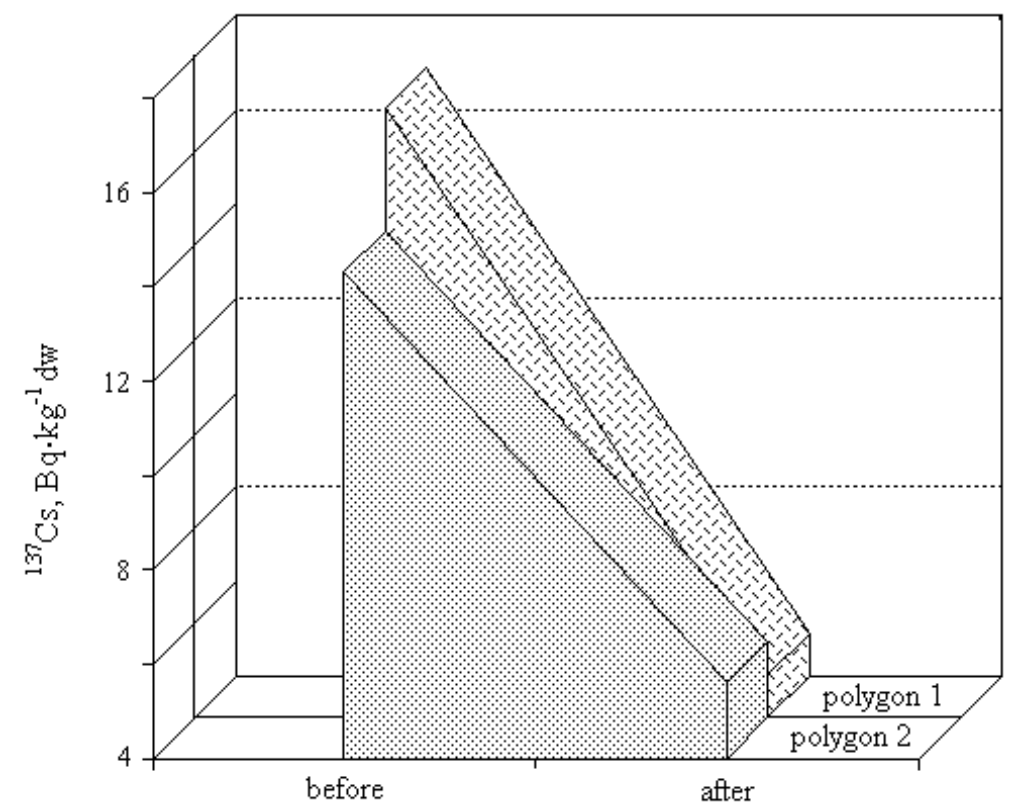

Fig. 6. ${ }^{137} \mathrm{Cs}$ in bottom sediments before and after irrigation of the model polygons PHYSICAL OCEANOGRAPHY NO. 3 (2015) 


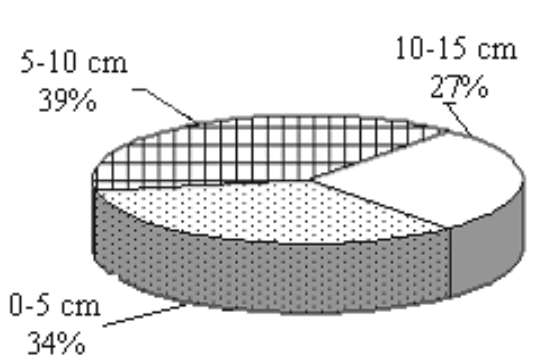

$a$

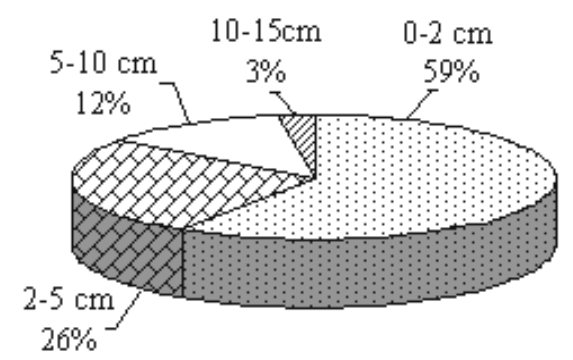

$b$

Fig. 7. ${ }^{137}$ Cs distribution in vertical profiles of soil under alfalfa (a) and the virgin soil (salt-marsh) (b)

The ratio between ${ }^{137} \mathrm{Cs}$ concentrations in the NCC bottom sediments collected on station 1 (Fig. 2) (22.4 - $\left.28.5 \mathrm{~Bq} \cdot \mathrm{kg}^{-1} \mathrm{dw}\right)$ and station $5 \mathrm{~A}\left(3.8-5.3 \mathrm{~Bq} \cdot \mathrm{kg}^{-1} \mathrm{dw}\right)$ was $5-6 .{ }^{137} \mathrm{Cs}$ concentrations in bottom sediments of the NCC branches canals (stations 4 and 5) were by 2.5 - 3.5 times higher than those from the discharge canals (stations 4A and 5A) (Fig. 6). Hence, the portion of radiocesium that inflowed the Karkinitsky Bay was about $5-6$ times lower than that at the NCC beginning $[1,4,10,11]$. Thus, a significant part $(94.2-98.3 \%)$ of radiocesium activity was extracted by the components of aquatic and terrestrial ecosystems while water passed through the NCC mainstream, its branches canals, agricultural soils and crops, and discharge canals $[1,4,10,11]$. Estimation of ${ }^{137}$ Cs transfer via the NCC water ecosystem including the irrigated agricultural lands shows that only about $1.7-5.8 \%$ of this radionuclides amount reached the Karkinitsky Bay [1, 4, 10, and 11].

In 1990 - 1995 activity of plutonium isotopes in the Dnieper water inflowing the NCC was $105 \mathrm{MBq}[1,2,9,10]$. Total concentration of plutonium isotopes in the Dnieper water changed from $5.6 \mathrm{mBq} \cdot \mathrm{m}^{-3}$ (close to the NCC entrance) to $3.2 \mathrm{mBq} \cdot \mathrm{m}^{-3}$ in its lateral branches $[1,2]$. Plutonium concentration in drainage waters after the irrigation process was equal to $1.3 \mathrm{mBq} \cdot \mathrm{m}^{-3}$. Therefore, a part of plutonium isotopes was accumulated by the components of water system and agricultural land ecosystems. Activity of plutonium isotopes on $1 \mathrm{~m}^{2}$ in the $0-5 \mathrm{~cm}$ layer of soil was $1.4-3.8 \mathrm{~Bq}$ for ${ }^{238} \mathrm{Pu}$ and $2.8-8.0 \mathrm{~Bq}$ for ${ }^{239,240} \mathrm{Pu}[11]$.

Activity of plutonium isotopes in bottom sediments in the branch canals constituted $40-45 \%$ of the corresponding value in the NCC mainstream. It was $0.25 \%$ of its activity that got to the NCC from the Kakhovka Reservoir. Thus, total activity of plutonium isotopes accumulated by bottom sediments and components of agricultural ecosystem was about $60 \%$ and $1 \mathrm{~m}^{2}$ of the irrigated soils accumulated about $4.2-4.7 \mathrm{mBq}$ of these isotopes [11].

During the first months after the ChNPP accident the NCC primary pollution by ${ }^{90} \mathrm{Sr}$ was caused by atmospheric fallout. At that time ${ }^{90} \mathrm{Sr}$ concentration increased from $52.3 \pm 3.6$ to $61.1 \pm 7.3 \mathrm{~Bq} \cdot \mathrm{m}^{-3}[1,2,12]$. Secondary ${ }^{90} \mathrm{Sr}$ pollution of the NCC was in spring, 1987. It was connected with this additional radionuclide portion that got to the Kakhovka Reservoir from the Chernobyl zone via the Dnie- 
per Reservoirs' cascade [3, 12]. As a result concentration of ${ }^{90} \mathrm{Sr}$ in the NCC water increased by about 9 times in comparison with 1986 [1, 2, 12]. It was found that content of ${ }^{90} \mathrm{Sr}$ in a particulate form was less than $1 \%$ as compared to the dissolved form. Therefore the role of the suspended matter in the ${ }^{90} \mathrm{Sr}$ transfer to the NCC ecosystem was insignificant [1, 2]. In $1992-1995$ concentrations of ${ }^{90} \mathrm{Sr}$ in the Dnieper water decreased from $216.6 \pm 9.7 \mathrm{~Bq} \cdot \mathrm{m}^{-3}$ at the NCC entrance to $135.0 \pm 5.7 \mathrm{~Bq} \cdot \mathrm{m}^{-3}$ on the distance $160 \mathrm{~km}[1,2]$. Concentrations of ${ }^{90} \mathrm{Sr}$ in the discharged water (stations 4A and 5A) (Fig. 2) were by $1.7-3.4$ times lower than those in the water before irrigation on the model polygons 1 and 2 (stations 4 and 5) (Fig. 2). Thus, about $29-58 \%$ of the initial amount of ${ }^{90} \mathrm{Sr}$ in the Dnieper water was accumulated by the irrigated crops and soils of agricultural lands under them $[1,2]$. It was calculated that ${ }^{90} \mathrm{Sr}$ concentrations in the Dnieper water in the NCC exponentially halved each 7.6 years $[12,13]$.

On the average in 1987 - 1999 a rate of biogeochemical self-purification of the NCC water ecosystem from ${ }^{90} \mathrm{Sr}$ was $80.9 \mathrm{GBq}$ per year. During this period general stock of ${ }^{90} \mathrm{Sr}$ in the NCC water decreased by 1051.2 GBq. By that time radioactive decay of ${ }^{90} \mathrm{Sr}$ reached $35 \%$ of this value. Estimation of ${ }^{90} \mathrm{Sr}$ concentration in the NCC water demonstrates that its decrease to the pre-accidental level will continue up to 2030 [13]. By that time the amount of ${ }^{90} \mathrm{Sr}$ in the NCC water will decrease by 3.8 times in comparison with the time of existence of $97 \%$ of its atoms. Total activity of strontium in water used for agricultural irrigation in the Crimea was about $5900 \mathrm{GBq}[12,13]$. At that time ${ }^{90} \mathrm{Sr}$ concentration in the NCC water did not achieve maximum permissible concentration for drinking water accepted in Ukraine in 1991 - 1997. However, in 1999 the pre-accidental level exceeded more than order values. In the NCC bottom sediments ${ }^{90} \mathrm{Sr}$ concentration depended on a distance of sampling location from its beginning [1, 2, 3, 13] (Fig. 8). Contribution of the NCC water irrigation system components to input of the ${ }^{90} \mathrm{Sr}$ to the Black Sea constituted $9-11 \%$ of its initial activity.

${ }^{90} \mathrm{Sr}$ concentrations in the soils of the NCC irrigated area depended on the sampling locations. They are independent of the crop species growing on the soils. Average concentration of ${ }^{90} \mathrm{Sr}$ in the soils under rice was lower by $23 \%$ than in the bottom sediments at the corresponding sample stations. The ${ }^{90} \mathrm{Sr}$ distribution in the vertical profile of agricultural soils (Fig. 9, $a$ ) is the same as that of its stable analog Ca (Fig. 9, $b$ ) [1, 3].

${ }^{90} \mathrm{Sr}$ accumulation by crops was not depended on distance of their cultivation area from the NCC beginning $[1,13] .{ }^{90} \mathrm{Sr}$ accumulation by alfalfa exceeded those revealed for other crops by $2-5$ times. Average ${ }^{90} \mathrm{Sr}$ concentrations in the crops changed in accordance to the following range: alfalfa $\left(6.4 \pm 0.4 \mathrm{~Bq} \cdot \mathrm{kg}^{-1} \mathrm{dw}\right)>$ rice $\left(2.4 \pm 0.2 \mathrm{~Bq} \cdot \mathrm{kg}^{-1} \mathrm{dw}\right)>$ wheat $\left(1.5 \pm 0.3 \mathrm{~Bq} \cdot \mathrm{kg}^{-1} \mathrm{dw}\right) \cong \operatorname{corn}\left(1.9 \pm 0.2 \mathrm{~Bq} \cdot \mathrm{kg}^{-1} \mathrm{dw}\right)$. The ${ }^{90} \mathrm{Sr}$ behavior in biota of investigated ecosystem is similar to those of stable Ca and $\mathrm{Sr}$ in the same species [1, 3]. In 1997 concentrations of ${ }^{90} \mathrm{Sr}$ in hydrophytes in the NCC water ecosystem reached their pre-accidental levels $[1,2,13]$. 


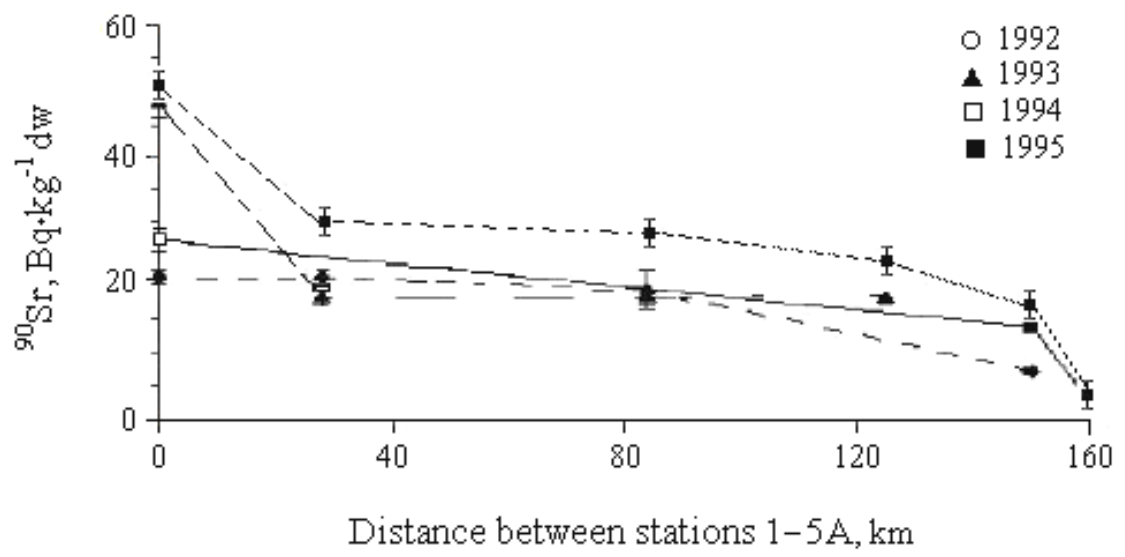

Fig. 8. Change of the ${ }^{90} \mathrm{Sr}$ concentration in bottom sediments of the mainstream of the NCC in 1992, 1993, 1994 and 1995

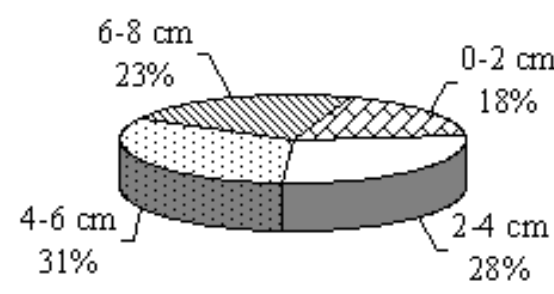

$a$

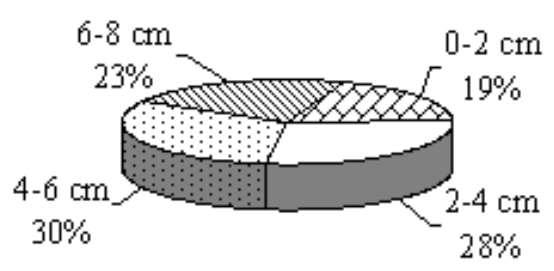

$b$

Fig. 9. ${ }^{90} \mathrm{Sr}(a)$ and $\mathrm{Ca}(b)$ in irrigated soils under alfalfa

Conclusion. The approaches applied in this study were used for estimating the role of the NCC irrigation system and its local polygons (considered as model objects) in transport of the Chernobyl origin long-lived radionuclides ${ }^{90} \mathrm{Sr}$ and ${ }^{137} \mathrm{Cs}$, and plutonium isotopes by the Dnieper water from the Kakhovka Reservoir to the Karkinitsky Bay.

${ }^{90} \mathrm{Sr}$ is characterized by almost uniform distribution in all the components of the NCC irrigation ecosystem. The contribution of this ecosystem to transfer of ${ }^{90} \mathrm{Sr}$ to the Karkinitsky Bay constituted $9-11 \%$ of its initial activity. The role of suspended matter in this process was insignificant. About $29-58 \%$ of the ${ }^{90} \mathrm{Sr}$ initial amount in the Dnieper water that got to the NCC irrigation system was accumulated by crops and the corresponding agricultural soils. During the period under study the ${ }^{90} \mathrm{Sr}$ concentrations in the NCC water did not reach the maximum permissible concentration for drinking water. It was calculated that ${ }^{90} \mathrm{Sr}$ concentration in the Dnieper water in the NCC halved each 7.6 years. On the average in $1987-$ 1999 the rate of biogeochemical self-purification of the NCC water from ${ }^{90} \mathrm{Sr}$ was $80.9 \mathrm{GBq}$ per year. It was estimated that ${ }^{90} \mathrm{Sr}$ concentration in the NCC water would achieve the ChNPP pre-accidental level by 2030. 
${ }^{137} \mathrm{Cs}$ in the Dnieper water, as well as plutonium isotopes, were found mainly in suspended matter. ${ }^{137} \mathrm{Cs}$ transfer via the NCC irrigation ecosystem showed that, on the average, $3.7 \%$ of this radionuclide reached the Karkinitsky Bay. About $94.2-98.3 \%$ of ${ }^{137} \mathrm{Cs}$ was extracted by the components of aquatic and terrestrial ecosystems while the Dnieper water moved in the NCC mainstream, its branch canals, agricultural soils, crops and discharge canals. Total activity of plutonium isotopes that got to the NCC equaled about $105 \mathrm{MBq}$. 77.7 MBq of this amount were involved in the irrigation process. Only about $0.25 \%$ of their initial activity reached the Karkinitsky Bay. It is evident that the irrigated agricultural soils, bottom sediments of the NCC mainstream, its branch and drainage systems constitute the main storage of ${ }^{137} \mathrm{Cs}$ and plutonium isotopes. Therefore, the NCC irrigation system is considered to be a natural buffer preventing further transfer of these radionuclides to the Karkinitsky Bay.

The conclusions resulted from research of long-lived Chernobyl origin radionuclides transported by the Dnieper water via the NCC demonstrate stable radiological situation. The represented data can serve a basis for comparative studies of the unforeseen environmental accidents.

\section{REFERENCES}

1. Lazorenko, G.E., Polikarpov, G.G. \& Mirzoyeva, N.Yu. [et al.], 1996, "Radiokhimichesky i tekologichesky monitoring vodnoy ecosistemy SKK i orosharmykh sel'skohozyastvennykh poley [Radiochemoecological monitoring of water ecosystem of the NCC and irrigated agricultural fields]", Trudy Mezhdun. Raboch. Gruppy "Radioekologiya: Dostizheniya i perspectivy”, 3-7 Okt., 1994, Sevastopol (Ukraina), Sevastopol, InBYuM, pp. 58-61 (in Russian).

2. Polikarpov, G.G., Lazorenko, G.E. \& Korotkov, A.A. [et al.], 1995, “Rol' otdel'nykh veshchestv $i$ donnykh otlozheniy $v$ vodnoy ekosisteme Severo-Kryskogo Kanala $v$ migratsii ${ }^{90} \mathrm{Sr}$, ${ }^{137} \mathrm{Cs},{ }^{238} \mathrm{Pu}$ and ${ }^{239+240} \mathrm{Pu}$ [The role of particular matters and bottom sediments of the Northern-Crimean Canal water ecosystem in a migration of ${ }^{90} \mathrm{Sr},{ }^{137} \mathrm{Cs},{ }^{238} \mathrm{Pu}$ и $\left.{ }^{239+240} \mathrm{Pu}\right]$ ”, Dokl. NAS Ukr., vol. 7, pp. 135-139 (in Russian).

3. $\quad$ Mirzoyeva, N.Yu., 1996, “Migratsiya ${ }^{90} \mathrm{Sr} v$ presnovodnykh ekosistemakh, prilegayushchikh $k$ ChNPP i na yuge Ukrainy [Migration of ${ }^{90} \mathrm{Sr}$ in freshwater ecosystems of the nearby zone of the ChNPP and the South of Ukraine]”, Trudy Mezhdun. Raboch. Gruppy "Radioekologiya: Dostizheniya i perspectivy”, 3-7 Okt., 1994, Sevastopol (Ukraina), Sevastopol, InBYuM, pp. 163-169 (in Russian).

4. Polikarpov, G.G., Lazorenko, G.E., 2008, “Vklad Severo-Kryskogo Kanala v perenos tseziya $v$ Karkinitsky zaliv Chernogo morya [The contribution of the Northern-Crimean Canal in a transport of caesium to the Karkinitsky Bay of the Black Sea]”, Trudy Mezhdunar. Conf. "Radiatsiyta i Ekosistemy”, 10-12 Okt. 2008, Gomel (Belorussiya), Gomel, RNIUP "Institut radiobiologii”, pp. 17-20 (in Russian).

5. Harvey, B.K., Ibbett, R.D. \& Lovett, M.B. [et al.], 1989, Analytical procedures for the determination of strontium radionuclides in environmental materials, Aquatic Environmental Protection: Analytical Methods, Lowestoft, UK, 33 p.

6. "Rukovodstvo po sanitarnomu kontrolyu radioaktivnykh veshchestv v obyektakh vneshney okruzhayushchey sredy" [Guidebook for sanitary control of the content of radioactive substances in the objects of the external environment]", 1980, Pod red. A.N. Marey, A.S. Zykova. Moscow, Institute of Biophysics AN USSR, 336 p. (in Russian).

7. Measurement of Radionuclides in Food and Environment. Guidebook, 1989, Technical Report Series 295, Vienna, IAEA, 523 p.

8. Talvitie, N.A., 1971, Radiochemical determination of plutonium in environmental and biological samples by ion exchange, Analyt. Chem, vol. 43, no. 13, pp. 1827-1830.

PHYSICAL OCEANOGRAPHY NO. 3 (2015) 
9. Tereshchenko, N.N., 1996, "Soderzhanie ${ }^{238} \mathrm{Pu},{ }^{239+240} \mathrm{Pu},{ }^{241} \mathrm{Am}$ and ${ }^{244} \mathrm{Cm} v$ donnykh otlozheniyakh i pochve $v$ zone, prilegayushchey $k$ ChNPP na yuge Ukrainy [Content of ${ }^{238} \mathrm{Pu}$, ${ }^{239+240} \mathrm{Pu},{ }^{241} \mathrm{Am}$ and ${ }^{244} \mathrm{Cm}$ in bottom sediment and soils nearby to them in close zone of ChNPP and at South of Ukraine]", Trudy Mezhdun. Raboch. Gruppy "Radioekologiya: Dostizheniya i perspectivy”, 3-7 Okt., 1994, Sevastopol (Ukraina), Sevastopol, InBYuM, pp. 177-183 (in Russian).

10. Lazorenko, G.E., 1998, "Raspredelenie khimicheskikh elementov i tseziya-137 v ekosisteme Cevero-Krymskogo Kanala [The distributions of chemical elements and caesium-137 in the Northern-Crimean Canal ecosystem]", Trudy Mezhdun. Konf. "SECOTOX 97. Konf. Stran Tsentr. i Vost. Evropy po voprosam ecotoksikologii bezopasnosti okruzhayushchey sredy, 2427 Avg. 1997, Jürmala (Latviya), Trudy Latv Akad. Nauk, Sekts. B, vol. 52, pp. 262-265.

11. Polikarpov, G.G., Lazorenko, G.E. \& Tereshchenko, N.N. [et al.], 2008, “Vklad irrigatsionnoy sistemy Severo-krymskogo Kanala v perrnos radionuclidov tseziya, plutoniya i ameritsiya vodami Dnepra v Karkinitsky zaliv Chernogo morya [The contribution of the NorthCrimean Canal irrigation system to transport of caesium, plutonium and americium radionuclides with the Dnieper waters into the Karkinitsky Bay of the Black Sea]", Radioecologicheskaya reaktsiya Chernogo morya na Chernobylkskuyu katastrofu, Pod. Red. G.G. Polikarpov, V.N. Egorov, Sevastopol, ECOSI-Gidrofizika, pp. 185-206 (in Russian).

12. "Baza dannykh RChBD InBYuM (za period 1964-2006): Voda. Gidrobionty. Donnye otlozheniya. Kompyuternaya Programma” [Database of RChBD of IBSS (for period 1964-2006): Water. Hydrobionts. Bottom sediments. Computer Programme], 2006, OR\&CHB: Razrabotano v 1992 v PARADOX, Sevastopol, InBYuM, 425 p. (in Russian).

13. Mirzoyeva, N.Yu., Polikarpov, G.G. \& Egorov, V.N., 2008, “90 $\mathrm{Sr} v$ vodnoy ekosisteme komponentov $v$ raione Chrnobylskoy NPP i na yuge Ukrainy $\left[{ }^{90} \mathrm{Sr}\right.$ in aquatic ecosystem components of the Chernobyl NPP near-field zone and in the South of Ukraine]”, Radioecologicheskaya reaktsiya Chernogo morya na Chernobylkskuyu katastrofu, Pod. Red. G.G. Polikarpov, V.N. Egorov, Sevastopol, ECOSI-Gidrofizika, pp. 129-168 (in Russian). 